\title{
Dodajanje vrednosti za odjemalce
}

\author{
Maja Peterc Zidar* \\ Fakulteta za organizacijske študije v Novem mestu, Ulica talcev 3, 8000 Novo mesto, \\ Slovenija \\ maja.peterc.zidar@fos-unm.si
}

\section{Uroš Skrinar}

Fakulteta za organizacijske študije v Novem mestu, Ulica talcev 3, 8000 Novo mesto, Slovenija

uros.skrinar@fos-unm.si

\begin{abstract}
Povzetek:
Raziskovalno vprašanje (RV): Kako oziroma na kakšen način se kaže odličnost organizacij pri dodajanju vrednosti za odjemalce?

Namen: Namen je preveriti rezultate pri posameznih podgradnikih izbranega gradnika Dodajanje vrednosti za odjemalce $\mathrm{v}$ dveh različnih obdobjih in jih primerjati, kot tudi analizirati strokovno literaturo.

Metoda: Uporabljeni in primerjani so bili rezultati izbranih obdobij FOŠ metra poslovne odličnosti, kot tudi izvedena analiza strokovne literature.

Rezultati: Rezultati kažejo nihanja v podanih ocenah gradnika v izbranem obdobju, kar je lahko posledica različnih dejavnikov, hkrati pa strokovna literature potrjuje naše raziskovalno vprašanje, da odlične organizacije upoštevajo vsa načela gradnika Dodajanje vrednosti za odjemalce.

Organizacija: S podanimi predlogi vplivamo na izboljšanje odličnosti organizacij. Z implementacijo predlogov lahko še izboljšamo vrednost za odjemalce ter $\mathrm{s}$ tem uspešnost organizacije na globalnem trgu.

Družba: Na dodano vrednost za odjemalce vplivajo vsi deležniki tako v kot zunaj organizacije. Zavedati se je potrebno, da le preplet vseh in zasledovanje vseh načel gradnika omogoča odličnost organizacije.

Originalnost: Ker so rezultati tudi iz leta 2020, pomeni, da so to zadnji rezultati podgradnikov, zato lahko opazimo vpliv glavnega dejavnika (Covid-19) na rezultate.

Omejitve/nadaljnje raziskovanje: $\mathrm{Za}$ dosego reprezentativnih rezultatov bi bilo potrebno primerjati še rezultate iz prejšnjih let in analizirati napredek/nazadovanje pri posameznih podgradnikih.
\end{abstract}

Ključne besede: dodana vrednost, odjemalci, organizacija, gradnik, podgradniki, analiza, ukrepi, deležniki. 


\section{Uvod}

Organizacija, ki je poslovno odlična, prepozna to kot pomemben temelj v doseganju globalne konkurenčnosti za gospodarstvo, javni sektor in seveda za posameznika. Eden temeljnih gradnikov modela Poslovne odličnosti EFQM je dodajanje vrednosti za odjemalce. Odličnost organizacije se kaže $\mathrm{s}$ tem, da dodaja dodano vrednost odjemalcu $\mathrm{z}$ razumevanjem, predvidevanjem in izpolnjevanjem potreb in pričakovanj odjemalca ter seveda izkoriščanjem priložnosti.

Ker so zahteve odjemalcev čedalje večje, zakonodaja pri sproščenju izdelkov na trg pa čedalje strožja, mora podjetje ustrezno odreagirati. S procesom globalizacije se veča tudi konkurenca, saj so to sedaj postali globalni tekmeci na nekdaj lokalnem tržišču. Zato je pomembno, da organizacije spremljajo in se primerjajo s konkurenco, se hitro odzivajo na spremembe, bolje predvidijo tržišča in se prilagodijo, pomembna pa je tudi proaktivnost - razvoj novih izdelkov in pristopov ter obvladovanje stroškov.

Če želijo biti organizacije pri vsem tem poslovno odlične, morajo poznati potrebe svojih odjemalcev, pretvarjati njihove potrebe v privlačne in trajnostne ponudbe, jih vključevati v svoj razvoj in se ustrezno odzvati na njihove povratne informacije. Poleg tega se pričakuje, da poslovno odlične organizacije gledajo na vse deležnike, ne le odjemalce. Tudi zaposlenim morajo zagotoviti pogoje za doseganje kar najboljše uporabniške izkušnje.

Z raziskovalno nalogo tako želimo ugotoviti, kako oziroma na kakšen način se kaže odličnost organizacije pri dodajanju vrednosti za odjemalce? Namen je zbrati in analizirati rezultate pri posameznih podgradnikih izbranega gradnika Dodajanje vrednosti za odjemalce $\mathrm{v}$ dveh različnih obdobjih in jih med sabo primerjati. Tako želimo ugotoviti tudi, ali organizacije upoštevajo vsa načela ali morebiti dajejo prednost in razvijajo le nekaj od načel.

\section{Teoretična izhodišča}

Zadnja desetletja so prinesla številne spremembe v notranjem in zunanjem poslovnem okolju, s katerimi so se morale soočiti organizacije: močna (mednarodna) konkurenca, hitre tehnološke spremembe, pospešena digitalizacija, zahtevnejši odjemalci, nadzor regulatorjev, skrb za okolje, itd... Organizacije so se na novonastale spremembe odzvale z uvajanjem izboljšav v njihovih procesih delovanja, z namenom udejanjanja načel poslovne odličnosti, ki vodijo v dvig njihove kakovosti. Proces izboljševanja kakovosti pa je usmerjen na pet področij; odjemalce, ljudi, inovacije, management in sisteme.

Glede opredelitve kakovosti, sta Piskar in Dolinšek (2006, str. 32-35) prišla do spoznanja, da je »kakovosten proizvod oziroma storitev tista, ki ustreza zahtevam odjemalca. Mogoče je, da kupec že prej določi tehnične specifikacije in jih je potrebno natančno upoštevati, mogoče pa je, da so tehnične specifikacije že določene in se jih kasneje prilagodi odjemalcu.« 
Namreč, kot navaja tudi Koubek: »Podjetje je odvisno od svojih kupcev, zato mora razumeti njihove potrebe, izpolnjevati njihove zahteve in si prizadevati za doseganje njihovih pričakovanj.« (Koubek, 2016, str. 25).

O tem govori tudi prvi gradnik EFQM, ki je kratica za European Foundation for Quality Management oziroma Evropska fundacija za upravljanje kakovosti. Pri razumevanju in obvladovanju poslovne odličnosti organizacije si lahko namreč pomagamo prav z modelom odličnosti EFQM. Model EFQM je svetovno priznan okvir upravljanja, ki organizacijam omogoča, da dosežejo uspeh tako, da merijo svojo pot na poti do preobrazbe, jim pomagajo razumeti vrzeli in možne rešitve, ki so na voljo ter jim daje moč za napredek in bistveno izboljšanje uspešnosti njihove organizacije. Model EFQM omogoča zaposlenim razumeti vzorčno-posledične povezave med tem, kaj njihova organizacija dela in rezultati, ki jih dosega. Model tako lahko koristi organizacijam katere koli velikosti ali sektorja kot tudi posameznikom, ki iščejo preizkušen okvir upravljanja.

In prav omenjeni prvi gradnik modela EFQM poimenovan Dodajanje vrednosti za odjemalce navaja: »Odlične organizacije dosledno dodajajo vrednost za odjemalce z razumevanjem, predvidevanjem in izpolnjevanjem potreb in pričakovanj ter izkoriščenje priložnosti« (Model odličnosti EFQM 2013, str.3).

V praksi ugotavljamo, da odlične organizacije (Model odličnosti EFQM 2013, str.3) :

- Vedo, katere so različne skupine njihovih odjemalcev, že obstoječe kot potencialne, ter predvidevajo njihove raznovrstne potrebe in pričakovanja;

- Pretvarjajo potrebe, pričakovanja in potencialne zahteve $v$ privlačne in trajne vrednostne ponudbe za obstoječe in potencialne odjemalce;

- Z odjemalci vzpostavljajo in vzdržujejo dialog, ki temelji na odprtosti in transparentnosti;

- Prizadevajo si za inoviranje in ustvarjanje vrednosti za svoje odjemalce ter jih po potreb vključujejo v razvoj novih in inovativnih izdelkov, storitev in izkušenj;

- Zagotavljajo svojim zaposlenim potrebne vire, kompetence in pooblastila, da bi dosegali čim boljšo uporabniško izkušnjo;

- Nenehno spremljajo in pregledujejo izkušnje in dojemanje svojih odjemalcev ter se ustrezno odzivajo na vsako povratno informacijo;

- Primerjajo uspešnost svojega delovanja z relevantnimi referenčnimi organizacijami (angl. benchmarks ) ter se učijo iz njihovih dobrih strani in priložnosti za izboljšave, da lahko ustvarijo čim večjo vrednost za odjemalce.

S pregledom in analiziranjem literature želimo tako ugotoviti odgovor na naše raziskovalno vprašanje kako in na kakšen način se kaže odličnost organizacij pri dodajanju vrednosti za odjemalce ter predvsem, ali organizacije upoštevajo vsa načela ali morebiti dajejo prednost in razvijajo le nekaj od načel. 


\section{Metoda}

Model raziskave prikazuje Slika 1, iz katere razberemo, da ima odlična organizacija zadovoljne uporabnike le, če pri svojem poslovanju upošteva načelo dodane vrednosti za odjemalce, ki se kaže bodisi v proizvodu, storitvi in nenazadnje samem odnosu.
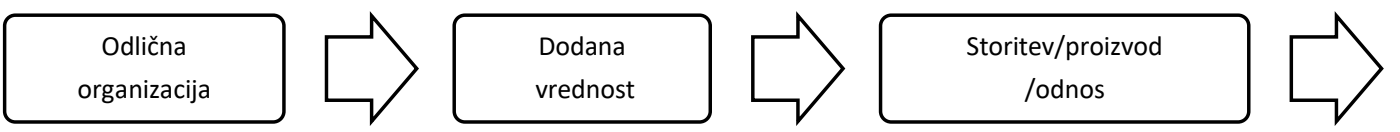

Slika 1. Model raziskave

Namen je zbrati in analizirati razpoložljive podatke glede gradnika Dodajanje vrednosti za odjemalce.

V raziskovalnem delu članka smo uporabili preglednico ocen FOŠmeter poslovne odličnosti preglednica ocen, ki povzema rezultate samoocenitve matičnih organizacij udeležencev Poletne šole FOŠ »Poslovna odličnost« in sicer 20 za leto 2018 in 49 za leto 2020.

Samoocenitev poslovne odličnosti je bila izvedena po metodologiji, ki jo je razvila Fakulteta za organizacijske študije v Novem mestu in temelji na modelu odličnosti EFQM. FOŠmeter poslovne odličnosti za vsakega od osmih gradnikov odličnosti podaja opise usmeritvenih trditev, pri čemer je bila za potrebe samoocenitve stopnja doseganja stanja vrednotena $\mathrm{V}$ razponu od 0 do 5 kot to predvideva metodologija modela CAF (Commmon Assesement Framework).

Hkrati smo izvedli metodo zbiranja podatkov s študijem literature na obravnavano temo. Gradivo smo pridobili v elektronski obliki na portalu Google učenjak, Cobiss, Dlib ter na spletni strani Fakultete za organizacijske študije. Podatke smo iskali s pomočjo ključnih besed, ki so navedene $\mathrm{v}$ Tabeli 1 .

Ker je za izbrano temo na voljo velika količina gradiva, tako v slovenskem kot tudi v tujem jeziku, je bilo potrebno smiselno filtrirati vso literaturo in skrbno izbrati najustreznejšo. Poskušali smo izbirati literaturo novejših letnikov (od leta 2015 dalje). Ker pa smo želeli tudi na nek način dobiti vpogled na to koliko se je pogled na odličnost glede dodajanja vrednosti za odjemalce skozi leta spreminjal, smo v našo raziskavo vključili tudi nekaj starejše datiranih virov, za katere smo smatrali, da so blizu odličnosti, ki jo model EFQM predstavlja.

Tabela 1. Iskanje člankov (uporabljene baze podatkov, ključne besede pri iskanju)

\begin{tabular}{lll}
\hline Baze podatkov & Ključne besede & Key words \\
Google učenjak, Cobiss, & dodana vrednost, odjemalci, zadovoljstvo, kupci, & added value, customers, \\
dLIB.si - digitalna knjižnica & analiza, podjetje, organizacija, kakovost, poslovna & company, measures, \\
Slovenije, FOŠ,... & odličnost, potrebe, pričakovanja & EFQM, quality \\
\hline
\end{tabular}

Tako zbrana študijska literatura je predstavljena $v$ Tabeli 2 in sicer po naslovu dela in avtorju. 
Tabela 2. Pregled literature

\begin{tabular}{|c|c|}
\hline Avtor (Letnica) & Naslov \\
\hline $\begin{array}{l}\text { Calvo-Mora, A., Navaro- García, A., } \\
\text { Periañez- Cristobal, R. (2015) }\end{array}$ & $\begin{array}{l}\text { Project to improve knowledge management and key business results } \\
\text { through the EFQM excellence model }\end{array}$ \\
\hline $\begin{array}{l}\text { Erceg, A., Dotlić, P., Mikuš, M. } \\
\text { (2016) }\end{array}$ & $\begin{array}{l}\text { The } 20 \text { keys methodology - Continous improvement for organizational } \\
\text { efficiency }\end{array}$ \\
\hline Fonseca, L. (2015) & $\begin{array}{l}\text { Relationship between ISO } 9001 \text { certification maturity and EFQM } \\
\text { business exellence model results }\end{array}$ \\
\hline Hojč, D. (2019) & Model vpliva dodane vrednosti za odjemalce ter inovativnost \\
\hline Koblar, M. (2010) & Management kakovosti \\
\hline Koubek, A. (2016) & Priročnik ISO 9001:2015 - Razumevanje in izvajanje novih zahtev \\
\hline Lanščak, I. (2020) & $\begin{array}{l}\text { Kaj koristnega prinaša uvedba modela poslovne odličnosti EFQMv } \\
\text { podjetje? }\end{array}$ \\
\hline Majcen, M. (2016) & $\begin{array}{l}\text { Vpliv cene na zadovoljstvo in zvestobo uporabnikov } \\
\text { telekomunikacijskih storitev }\end{array}$ \\
\hline Petelin, T. (2016) & Dodana vrednost programov zvestobe trgovinskih organizacij \\
\hline Piskar, S. \& Dolinšek, S. (2006) & Učinki standarda kakovosti ISO. \\
\hline Šmigoc, M. (2017) & $\begin{array}{l}\text { Primerjava zadovoljstva in zvestobe med odjemalci različnih } \\
\text { trgovinskih organizacij }\end{array}$ \\
\hline Vandermerwe, S. (2002) & $\begin{array}{l}\text { The Customer - connected Company: And the tole of e-Techonology in } \\
\text { Making it Happen }\end{array}$ \\
\hline Verstovšek, S. (2009) & $\begin{array}{l}\text { Analiza ravnanja odnosov z odjemalci - CRM (customer relationship } \\
\text { management) kot oblika modernega trženja, konceptualni model } \\
\text { ključnih dejavnikov uspeha CRM in empirična preverba : doktorska } \\
\text { disertacija }\end{array}$ \\
\hline Zupan, N., Kern, K. (2004) & Kakovost v izobraževalnem procesu \\
\hline Žibert, Ž. (2010) & $\begin{array}{l}\text { Dodana vrednost ISO14001 in ISO } 9001 \text { standarda v podjetju } \\
\text { Montana d.o.o. }\end{array}$ \\
\hline Yuan in Chen (2002) & $\begin{array}{l}\text { A study of VRM - awareness enterprise website. Expert Systems with } \\
\text { Applications, } 22 \text { (2), 147-162 }\end{array}$ \\
\hline
\end{tabular}

$S$ pregledom in analiziranjem zbrane literature smo pridobili podatke za oblikovanje odgovora na naše raziskovalno vprašanje kako in na kakšen način se kaže odličnost organizacij pri dodajanju vrednosti za odjemalce ter predvsem, ali organizacije upoštevajo vsa načela ali morebiti dajejo prednost in razvijajo le nekaj od načel. 
Revija za univerzalno odličnost / Journal of Universal Excellence,

GRADNIKI POSLOVNE ODLIČNOSTI

Marec 2021, leto / year 10, številka / number 1, str. / pp. 1-13.

Tabela 3. Tabela ključnih ugotovitev po posameznih referencah

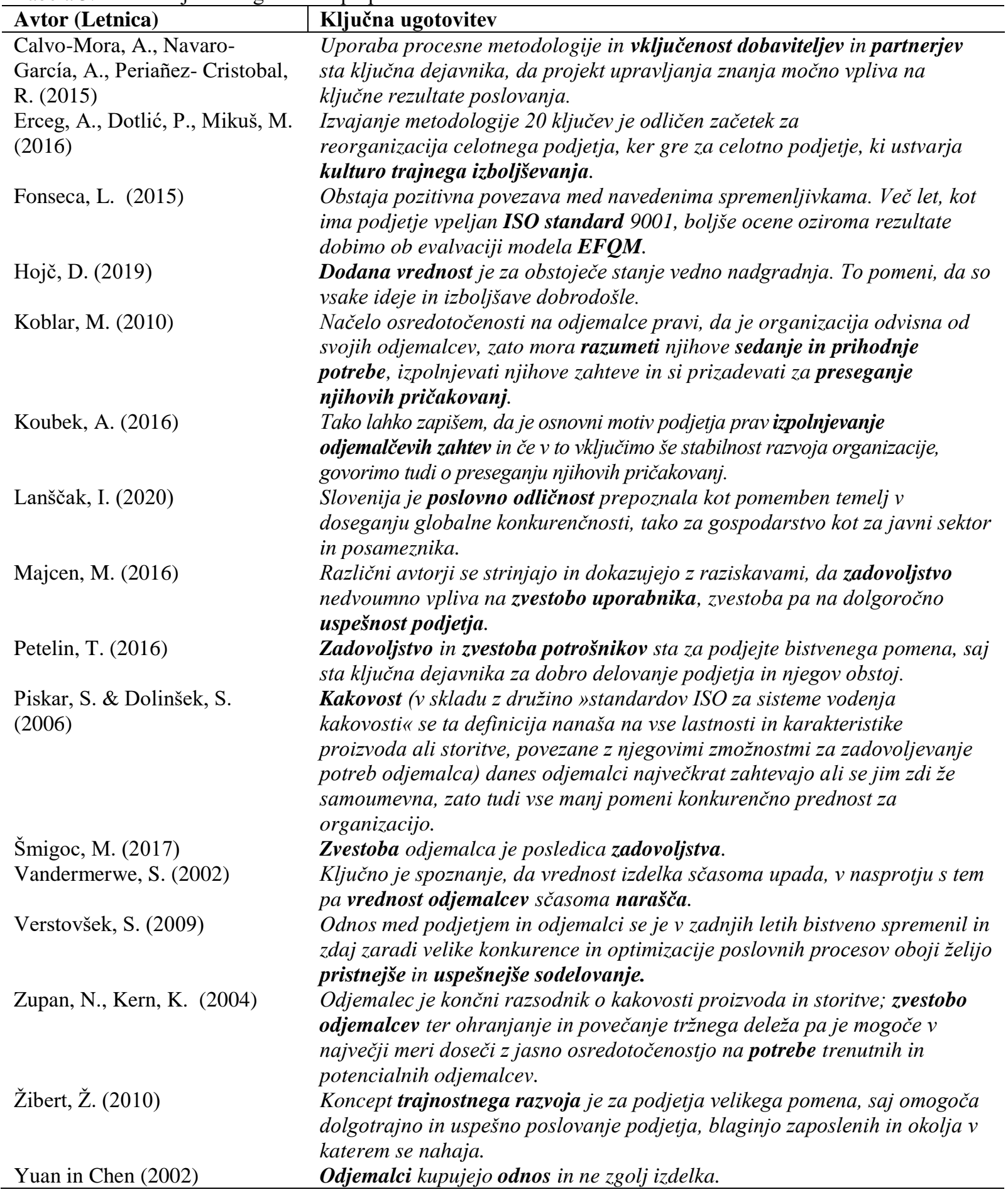

\section{Rezultati in razprava}

\subsection{Raziskava gradnika odličnosti}

S pomočjo analiziranja zbrane literature smo iskali odgovore na naše raziskovalno vprašanje kako in na kakšen način se kaže odličnost organizacij pri dodajanju vrednosti za odjemalce ter predvsem, ali organizacije upoštevajo vsa načela ali morebiti dajejo prednost in razvijajo le 
nekaj od načel obravnavanega gradnika. Ključne ugotovitve po referencah so zbrane in prikazane v Tabeli 3 .

Gradnik modela EFQM poimenovan Dodajanje vrednosti za odjemalce navaja, da »odlične organizacije dosledno dodajajo vrednost za odjemalce z razumevanjem, predvidevanjem in izpolnjevanjem potreb in pričakovanj ter izkoriščenje priložnosti«. (Model odličnosti EFQM 2013, str.3).

V praksi to pomeni, da odlične organizacije vedo, katere so različne skupine njihovih odjemalcev ter predvidevajo in pretvarjajo njihove potrebe in pričakovanja v privlačne in trajne vrednostne ponudbe za obstoječe in potencialne odjemalce kar potrjuje tudi Koubek (2016, str. 25), ki navaja, da »je osnovni motiv podjetja prav izpolnjevanje odjemalčevih zahtev in če $v$ to vključimo še stabilnost razvoja organizacije, govorimo tudi o preseganju njihovih pričakovanj«

Za doseganje le tega, je tudi ključno, da z odjemalci vzpostavljajo in vzdržujejo dialog, ki temelji na odprtosti in transparentnosti saj, kot navajata Yuan in Chen (2002, str. 150): »Odjemalci kupujejo odnos in ne zgolj izdelka«.

Vandermerwe (2002, str. 5) pa navaja, da je »ključno spoznanje, da vrednost izdelka sčasoma upada, v nasprotju s tem pa vrednost odjemalcev sčasoma narašča«, zato je ključno, da si odlične organizacije, kot opredeljuje tudi gradnik, ves čas prizadevajo za inoviranje in ustvarjanje vrednosti za svoje odjemalce

Odlične organizacije nenehno spremljajo in pregledujejo izkušnje in dojemanje svojih odjemalcev ter se ustrezno odzivajo na vsako povratno informacijo, kar opisuje tudi Koblar (2010, str. 296) v svojem prispevku in pravi, da je »načelo osredotočenosti na odjemalce tako, da je organizacija odvisna od svojih odjemalcev, zato mora razumeti njihove sedanje in prihodnje potrebe, izpolnjevati njihove zahteve in si prizadevati za preseganje njihovih pričakovanj«.

Piskar \& Dolinšek (2006, str. 13) opredeljujeta, da »kakovost danes odjemalci največkrat zahtevajo ali se jim zdi že samoumevna, zato tudi vse manj pomeni konkurenčno prednost za organizacijo«, s čimer se potrjuje to, da odlične organizacije uspešnost svojega delovanja primerjajo z relevantnimi referenčnimi organizacijami ter se iz tega učijo, da ustvarijo čim večjo kakovost in večjo vrednost za svoje odjemalce.

Kot opredeljujejo Calvo, Navaro \& Periañez (2015, str. 11) v svojem prispevku, da sta »uporaba procesne metodologije in vključenost dobaviteljev in partnerjev ključna dejavnika, da projekt upravljanja znanja močno vpliva na ključne rezultate poslovanja«, iz česar lahko povzamemo, da odlična podjetja pretvarjajo potrebe, pričakovanja in potencialne zahteve $\mathrm{v}$ privlačne in trajne vrednostne ponudbe za obstoječe in potencialne odjemalce. 
Ne le osredotočenost na odjemalce, potrebno je upoštevati vse deležnike v procesu. Kot navaja Žibert (2010, str. 2) je »koncept trajnostnega razvoja za podjetja velikega pomena, saj omogoča dolgotrajno in uspešno poslovanje podjetja, blaginjo zaposlenih in okolja v katerem se nahaja « in na tak način podjetja zagotavljajo svojim zaposlenim potrebne vire, kompetence in pooblastila, da bi dosegali čim boljšo uporabniško izkušnjo.

Na podlagi navedenega vidimo torej, kako se kaže odličnost organizacij ter lahko tudi zaključimo, da organizacije upoštevajo vsa načela, dejansko jih morajo, v kolikor želijo biti v današnjem globaliziranem svetu uspešna.

\subsection{Analiza gradnika FOŠ metra poslovne odličnosti}

Na podlagi zbranih podatkov v preglednici ocen FOŠmetra poslovne odličnosti, Fakulteta za organizacijske študije, smo za izbrani gradnik oblikovali tabelo (Tabela 4) s povprečnimi vrednostmi ocen po posameznem podgradniku kot tudi za celoten gradnik. V prvem stolpcu je prikazana povprečna ocena za gradnik in posamezen podgradnik za leto 2018 , v drugem za 2020 ter v tretjem skupna povprečna ocena za obe izbrani leti skupaj, ki nam služi za analizo doseganja gradnika.

V Tabeli 4 imamo zapisano analizo FOŠ metra poslovne odličnosti, natančneje analizo gradnika dodajanja vrednosti za odjemalce. Vrednosti tako za leto 2018 in 2020 ter skupna vrednost so nam bile podane.

Povprečna ocena za gradnik Dodajanje vrednosti za odjemalce v letu 2018 znaša 4,04; z najnižjo oceno zaznano pri podgradniku 1.7, ki znaša 3,8; medtem ko je najvišja ocena pri podgradniku 1.1 in znaša 4,35 . 
Marec 2021, leto / year 10, številka / number 1, str. / pp. 1-13.

Tabela 4. Analiza gradnika: Dodajanje vrednosti za odjemalce

\begin{tabular}{|c|c|c|c|c|}
\hline & & $\begin{array}{c}\text { POVPREČJE } \\
2018\end{array}$ & $\begin{array}{c}\text { POVPREČJE } \\
2020\end{array}$ & $\begin{array}{l}\text { SKUPNO } \\
2018 \text { in } \\
2020\end{array}$ \\
\hline 1 & $\begin{array}{l}\text { Vedo, katere so različne skupine njihovih odjemalcev, že } \\
\text { obstoječe kot potencialne, ter predvidevajo njihove } \\
\text { raznovrstne potrebe in pričakovanja; }\end{array}$ & 4,35 & 4,16 & 4,22 \\
\hline 2 & $\begin{array}{l}\text { Pretvarjajo potrebe, pričakovanja in potencialne zahteve v } \\
\text { privlačne in trajne vrednostne ponudbe za obstoječe in } \\
\text { potencialne odjemalce; }\end{array}$ & 4,1 & 3,73 & 3,84 \\
\hline 3 & $\begin{array}{l}Z \text { odjemalci vzpostavljajo in vzdržujejo dialog, ki temelji na } \\
\text { odprtosti in transparentnosti; }\end{array}$ & 4,05 & 4,08 & 4,07 \\
\hline 4 & $\begin{array}{l}\text { Prizadevajo si za inoviranje in ustvarjanje vrednosti za svoje } \\
\text { odjemalce ter jih po potrebi vključujejo v razvoj novih in } \\
\text { inovativnih izdelkov, storitev in izkušenj; }\end{array}$ & 4,05 & 3,84 & 3,90 \\
\hline 5 & $\begin{array}{l}\text { Zagotavljajo svojim zaposlenim potrebne vire, kompetence in } \\
\text { pooblastila, da bi dosegali čim boljšo uporabniško izkušnjo; } \\
\text { Nenehno spremljajo in pregledujejo izkušnje in dojemanje }\end{array}$ & 3,95 & 3,94 & 3,94 \\
\hline 6 & $\begin{array}{l}\text { svojih odjemalcev ter se ustrezno odzivajo na vsako povratno } \\
\text { informacijo; }\end{array}$ & 4 & 3,76 & 3,83 \\
\hline 7 & $\begin{array}{l}\text { Primerjajo uspešnost svojega delovanja z relevantnimi } \\
\text { referenčnimi organizacijami ter se učijo iz njihovih dobrih } \\
\text { strani in priložnosti za izboljšave, da lahko ustvarijo čim } \\
\text { večjo vrednost za odjemalce. }\end{array}$ & 3,8 & 3,94 & 3,90 \\
\hline & $\begin{array}{l}\text { Odlične organizacije dosledno dodajajo vrednost za } \\
\text { odjemalce z razumevanjem, predvidevanjem in } \\
\text { izpolnjevanjem potreb in pričakovanj ter izkoriščanjem } \\
\text { priložnosti. }\end{array}$ & 4,04 & 3,92 & 3,96 \\
\hline
\end{tabular}

Opomba. Povzeto in prirejeno po FOŠmeter poslovne odličnosti: Preglednica ocen

V letu 2020 znaša povprečna ocena 3,92 kar je za 0,12 manj kot v letu 2018, kar pomeni, da se je organizacija pri tem gradniku poslabšala. Najvišja ocena v 2020 je tako kot v letu 2018 pri podgradniku 1.1 in znaša 4,16 , najnižja ocena pa pri podgradniku 1.2 in znaša 3,73

Skupno povprečje obeh let je tako 3,96, z najnižjo povprečno oceno pri podgradniku 1.6, ki znaša 3,83 in najvišjo pri podgradniku 1.1, ki znaša 4,22.

Največji napredek v letu 2020 v primerjavi z 2018 je bil zaznam pri podgradniku 1.7 (in sicer povečanje za 0,06 ), največje nazadovanje pa pri podgradniku 1.2 in sicer iz 4,01 v letu 2018 na 3,73 v letu 2020 kar predstavlja razliko v vrednosti 0,37 .

Glede na ugotovljeno, lahko podamo predloge sistemskih pristopov za izboljšave in sicer glede:

- pričakovanj in zahtev odjemalcev, ki niso bile v celoti izpolnjene, je potrebno preveriti na katerem področju in kaj je tisto, kar bi zadovoljilo potrebe odjemalcev in to postopoma implementirati.

- nenehnega spremljanja in pregledovanja izkušenj in dojemanj odjemalcev, ki se je poslabšalo, je potrebno okrepiti spremljanje povratnih informacij s strani odjemalcev z novimi metodami in kontinuirano.

- neustreznega odzivanja na povratne informacije s strani odjemalcev, je potrebno vzpostaviti sistem analiziranja prejetih informacij in ustrezno reagiranje na podlagi ugotovitev. 
- primerjave z relevantnimi referenčnimi organizacijami, ki ni bila izvedena, se naj naredi raziskava trga (tudi tujega), kjer se pregleda njihovo delovanje in poskuša dobre praske postopoma, korak za korakom vpeljati v organizacijo.

\section{Zaključek}

V članku smo si zastavili vprašanje, kako oziroma na kakšen način se kaže odličnost organizacije pri dodajanju vrednosti za odjemalce. Preko metode zbiranja in analiziranja razpoložljivih podatkov glede gradnika Dodajanje vrednosti za odjemalce smo prišli do rezultatov, na podlagi katerih lahko potrdimo naše raziskovalno vprašanje. Namreč, v analizirani literaturi, ki zaobjema številne priznane mednarodne analize in raziskave, najdemo številne ugotovitve, ki potrjujejo, da je organizacija lahko v svojem poslanstvu odlična le, če je osredotočena na svoje odjemalce, "razume njihove sedanje in prihodnje potrebe, izpolnjuje njihove zahteve in si prizadeva za preseganje njihovih pričakovanj«, kot odlično povzame Vandermerwe (2002, str. 5). Tudi številna druga dela in avtorji potrjujejo naše raziskovalno vprašanje, kje smo se osredotočili tudi na to ali organizacije upoštevajo vsa načela ali morebiti dajejo prednost in razvijajo le nekaj od načel gradnika Dodajanje vrednosti za odjemalce po modelu Poslovne odličnosti EFQM. Analiza literature pokaže in dokaže, da je ključno, da organizacije razvijajo in negujejo vsa načela, saj so le tako lahko uspešna pri celostni obravnavi za svoje odjemalce. In, kot ugotavljamo že zgoraj, da predvsem z odjemalci vzpostavljajo in vzdržujejo dialog, ki temelji na odprtosti in transparentnosti saj, kot navajata Yuan in Chen (2002, str. 150): »Odjemalci kupujejo odnos in ne zgolj izdelka«, kar je v današnjem globalnem in dinamičnem svetu ključno, za obstanek organizacij. Iz vsega navedenega torej sledi, da le dosledno dodajanje vrednosti za odjemalce $\mathrm{z}$ razumevanjem, predvidevanjem in izpolnjevanjem njihovih potreb in pričakovanj ter izkoriščanjem priložnosti, omogoča organizaciji njeno odličnost.

Razumevanje dogajanj v hitro se globaliziranem svetu, neprestano se spreminjajočih potreb in zahtev ter zmožnost smiselnega reagiranja na izzive je ključnega pomena, da organizacije obstanejo in predvsem, da se prilagajajo in razvijajo. K temu pripomorejo tudi naloge, kot je ta, ki analizirajo in raziskujejo ugotovitve glede poslovne odličnosti organizacij ter $\mathrm{s}$ tem povečujejo znanje v organizaciji kot tudi v družbi širše, s čimer pa odpirajo morebitna nova vprašanja v stroki. Stalni premislek in raziskovanja pa omogočajo napredek in razvoj.

Globalizacije prinaša organizacijam čedalje večjo konkurenco in nujo, da so globalni tekmeci na nekdaj lokalnem tržišču. Organizacije so prisiljene ponuditi večje in boljše svojim odjemalcem, ki pričakujejo za svoj denar ne le najbolj kakovostni produkt, pač pa tudi nadpovprečen servis ter predvsem edinstven odnos. Organizacije in menedžerji morajo zato ves čas spremljati stanje na trgu ter biti proaktivni v spremembah. Spremljanje procesov, postopkov dela, odnosa je zato ključen za uspešnost organizacije in prav to smo raziskovali in potrdili v tej nalogi. Odličnost organizacije, s tem pa tudi način vodenja le te in odnosa menedžmenta se kaže $\mathrm{v}$ temu, da dodaja dodano vrednost odjemalcu $\mathrm{z}$ razumevanjem, predvidevanjem in 
izpolnjevanjem potreb in pričakovanj odjemalca. To pa posledično pomeni, da mora organizacija redno spremljati in se izboljševati $v$ vseh točkah, zato je ključno, da ima vzpostavljen sistem lastne evalvacije in spremljanja napredka.

Modeli mednarodnih standardov in poslovne odličnosti so dinamični, zato se spremembe dogajajo in se bodo dogajale ves čas. To lahko predstavlja tudi omejitev za analizo narejeno v tem članku kar posledično pomeni, da to predstavlja tudi omejitev za bolj poglobljene študije, ki so bile do sedaj že izvedene.

Prihodnje študije je treba izvesti v skladu s pričakovanimi standardi ISO 9001 in EFQM za še transparentnejši pregled načina dodajana vrednosti za odjemalce, za doprinos doseganju poslovne odličnosti in trajnostnega uspeha podjetja. Prav tako je za izbrano temo na voljo veliko gradiva tako $\mathrm{v}$ slovenskem kot $\mathrm{v}$ tujem jeziku, zato je pomembno, da se literatura neprestano nadgrajuje in da se pri raziskavi uporabijo novejši viri, če je to le mogoče. Kljub temu pa ne gre spregledati tudi starejše datiranih zapisov in raziskav, saj le tako lahko dobimo transparentnješo sliko in vpogled na spreminjanje, konec koncev napredek na izbranem področju. $\mathrm{V}$ bodoče bi bilo smiselno zbrati ugotovitve bodisi enega podjetja $\mathrm{v}$ več letnem obdobju (vsaj desetih let) ali pa ugotovitve menedžerjev, ki vodijo odlična podjetja in jih med seboj primerjati.

\section{Reference}

1. Bradley L., Fisher M., Ludwig W. (2012). Priročnik za uporabnike EFQM: Management dokument EFQM

2. Calvo-Mora A., Navaro- García A., Periañez- Cristobal R. (2015). International Journal of Project Management. Project to improve knowledge management and keybusiness results through the EFQM excellence model, 33(8), 1638-1651.

3. Erceg A., Dotlić P., Mikuš M. (2016). Studia Universitatis Babes-Bolyai Oeconomica. The 20 key methodology - Continous improvement fororganizational efficiency, 63(1).

4. Fonseca L. (2015). Quality Innovation Prosperity. Relationship between ISO 9001 certification maturity and EFQM business excellence model results 19(1), 85-102. Pridobljeno 3.12.2020 na https://pdfs.semanticscholar.org/2104/cf8dde732392ed1b11de6a5f20bea45a4184.pdf?_ga=2.7029 0960.1243124906.1606991511-852135741.1606991511

5. »FOŠmeter poslovne odličnosti: Preglednica ocen« (2020).

6. Hojč D. (2019). Revija za univerzalno odličnost. Model vpliva dodane vrednosti za odjemalce ter inovativnost, 8(2), 169-179. Pridobljeno 13.11.2020 na https://www.fosunm.si/media/pdf/RUO/2019-8-2/Hojc.pdf

7. Kern Pipan K. (2012). Pregled modela odličnosti EFQM 8(3). Pridobljeno 20.11.2020 na https://www.podjetniskiportal.si/uploads/gradiva/poslovna_odlicnost/efqm_model_odlicnosti/l_pregled_modela_efq m_2013-zv.pdf 
Revija za univerzalno odličnost / Journal of Universal Excellence,

GRADNIKI POSLOVNE ODLIČNOSTI

Članek / Article

Marec 2021, leto / year 10, številka / number 1, str. / pp. 1-13.

8. Koblar M. (2010). Zbornik 7. Festivala raziskovanja ekonomije in managementa, 2.-3. december 2010. Koper - Celje - Škofja Loka. Management kakovosti (str. 295-304). Pridobljeno 27.11.2020 na http://www.fm-kp.si/zalozba/ISBN/978-961-266-122-9/prispevki/031.pdf

9. Koubek, A. (2016). Priročnik ISO 9001:2015 - Razumevanje in izvajanje novih zahtev. Ljubljana, Pridobljeno 24.11.2020 na http://kakovosten.si/2017/10/11/osredotocenost-na-odjemalce/

10. Lanščak I. (2020). Kaj koristnega prinaša uvedba modela poslovne odličnosti EFQM v podjetje? Razvojni center Murska Sobota. Regionalna razvojna agencija za Pomurje. Pridobljeno 3.12.2020 na https://www.rcms.si/upload/files/1B\%20\%C4\%8Clanek\%20EFQM.pdf

11. Majcen M. (2016). Vpliv cene na zadovoljstvo in zvestobo uporabnikov telekomunikacijskih storitev. Univerza v Mariboru, Ekonomsko-poslovna fakulteta, Maribor. Pridobljeno, 28.11.2020 na https://dk.um.si/Dokument.php?id=91406

12. Miguel L. (2015). Quality Innovation Prosperity. Relationship between ISO9001 certification maturity and EFQM business excellence model results, 19(1), 85-102

13. Generalni sekretariat Vlade RS, Sektor za prevajanje (2012) Model odličnosti EFQM 2013. Ljubljana, Ministrstvo za gospodarski razvoj in tehnologijo, Urad RS za meroslovje (MIRS)

14. Petelin T. (2016) Dodana vrednost programov zvestobe trgovinskih organizacij. Univerza v Mariboru, Ekonomsko-poslovno fakulteta, Maribor. Pridobljeno 3.12.2020 na https://dk.um.si/Dokument.php?id=85905

15. Piskar, S. \& Dolinšek, S. (2006). Učinki standarda kakovosti ISO. Koper. Univerza na Primorskem, Fakulteta za management Koper.

16. Slovensko združenje za kakovost in odličnost. (2019). Kakovost. https://www.dropbox.com/s/6kin3yd3f6cx8im/Kakovost_2019-02.pdf?dl=0

17. Šmigoc M. (2017) Primerjava zadovoljstva in zvestobe med odjemalci različnih trgovinskih organizacij. Univerza v Mariboru, Ekonomsko-poslovna fakulteta, Maribor. Pridobljeno 2.12.2020 na https://dk.um.si/Dokument.php?id=118184

18. Vandermerwe, Sandra (2002). The Customer - connected Company: And the tole of eTechonology in Making it Happen. Pridobljeno 2.12.2020 na https://mthink.com/legacy/www.crmproject.com/content/pdf/CRM1_wp_vandermerwe.pdf

19. Yuan Soe-Tsyr, Chen Ho-Shing (2002): A study of VRM - awareness enterprise website. Expert Systems with Applications, 22 (2), 147-162

20. Verstovšek, Sintija (2009: Analiza ravnanja odnosov z odjemalci - CRM (customer relationship management) kot oblika modernega trženja, konceptualni model ključnih dejavnikov uspeha CRM in empirična preverba (doktorska disertacija). Pridobljeno 2.12.2020 na https://plusup.si.cobiss.net/opac7/bib/epf/18461926

21. Zupan N., Kern K. zbornik referatov 23. mednarodne znanstvene konference o razvoju organizacijskih ved "Management, znanje in EU" v Portorožu 24. - 26.3. 2004. Kakovost v izobraževalnem procesu. (str. 820-828). Pridobljeno 29.11.2020 na https://www.podjetniskiportal.si/uploads/gradiva/poslovna_odlicnost/gradiva_pod_poslovno_odlinost/49_kakovostvizobra zevanju.pdf

22. Žibert Ž. (2010) Dodana vrednost ISO14001 in ISO 9001 standarda v podjetju Montana d.o.o.. Univerza v Mariboru, Ekonomsko poslovna fakulteta Maribor. Pridobljeno 30.11.2020 na https://core.ac.uk/download/pdf/67539541.pdf 
Maja Peterc Zidar je študentka prvega letnika izrednega podiplomskega študija na Fakulteti za organizacijske študije v Novem mestu, smer menedžment kakovosti. Oktobra 2012 je diplomirala na Biotehniški fakulteti v Ljubljani. Kot študentka si je pridobivala delovne izkušnje $\mathrm{z}$ delom $\mathrm{v}$ javni upravi na občini, pozneje $\mathrm{z}$ delom $\mathrm{s}$ strankami v največji Slovenski energetski družbi. Nato se je zaposlila kot delavka v proizvodnji v avto-moto industriji, natančneje na oddelku kompoziti. Kasneje je 6 let opravljala delo vodje oddelka polimernih/kompozitnih materialov, ima tudi licenco za potrjevanje nacionalne pokline kvalifikacije za poklic Izdelovalec plastičnih kompozitnih izdelkov. Od leta 2019 svoje delo opravlja kot pomočnik referenta ključnih strank na segmentu titanovih ulitkov.

Uroš Skrinar je diplomirani ekonomist, diplomant Fakultete Doba, trenutno na funkciji direktorja Nacionalne agencije EU programov Erasmus+: Mladi v akciji in Evropska solidarnostna enota v Sloveniji si v svojem profesionalnem delu prizadeva za dvig kakovosti mladinskega dela v Sloveniji, na katerem področju je objavil kar nekaj strokovnih člankov.

\section{Abstract: Adding Value for Customers}

Research Question (RQ): How or in what way is the excellence of companies in adding value for customers manifested?

Purpose: The purpose is to check the results of individual sub-subsets of the selected widget called Adding Value for Clients in two different periods and to compare them

Method: The results of selected periods have been used and compared, and we analyse them and, based on the analysis, propose measures for improvements

Results: The results show fluctuations in the given building block estimates over the selected period, which may be due to various factors.

Organization: With the given suggestions, we influence the improvement of the company's excellence. By implementing the proposals, we can further improve the value for customers

Society: Value added for customers is influenced by all stakeholders in the company - management and employees. It is necessary to be aware that they can only be more successful together and with consistent implementation of measures.

Originality: Since the results are also from 2020, it means that these are the latest results of the subbuilders, so we can see the influence of the main factor (Covid 19) on the results

Limitations/Future Research: In order to achieve representative results, it would be necessary to compare the results from previous years and analyse the progress / decline in individual subcontractors

Keywords: added value, customers, building block, substructures, analysis, measures, stakeholders, company. 